\title{
CORPORATE GOVERNANCE IN THE DIGITAL ERA - THEORETICAL CONSIDERATIONS
}

\author{
Paweł Zieliński \\ Czestochowa University of Technology \\ Faculty of Management
}

\begin{abstract}
Constantly increasing speed of technical development as well as changes in social behavior of human makes picture of entrepreneur activity quite dynamically changing. Corporate governance in order to keep up with those changes requires fast adaptations as well. But is it possible at all? Can we define pillars of transparency, and stability in the way which allows adaptive mechanism embedded? Few examples from real world of Corporate Governance are used here to support discussion points aiming more in formulating questions, and naming problems expanding traditional understanding of the topics with tomorrow's challenges coming today.
\end{abstract}

Keywords: agency theory, big data, corporate governance, digitalization, stewardship

DOI: $10.17512 /$ znpcz.2018.1.18

\section{Introduction}

The most common definition of corporate governance is related to the "collection of control mechanisms that an organization adopts to prevent or dissuade potentially self-interested managers from engaging in activities detrimental to the welfare of shareholders and stakeholders" (Larcker, Tayan, 2016; Grabowska 2016; Brzozowska, Pawełoszek, Turek 2016). The governance definition by World Bank says: "the exercise of political authority and the use of institutional resources to manage society's problems and affairs". According to the economic view corporate governance has an influence on the vitality and integrity of the economic system (Mohamed, Ratnatunga 2008). Corporate governance in this point of view provides a framework for the division of labor and financial results in a company (Guillen 2000).

However, not only for the purpose of this paper, but generally whenever that term is in use we may keep in mind two other possible interpretations. First, according to the narrowest, legal definition corporate governance is the distribution of competences among statutory bodies of a limited liability or joint-stock company (Larcker, Tayan 2016). The opposite approach, the broadest (systematic) definition, sees corporate governance as the collection interdependent and complementary legal and economic institutions, aiming at ensuring correct and economically effective operation of joint-stock companies (in particular public companies) (OECD 2004) and solving or at least mitigating the contradictions (conflicts) of people's interests involved in the company. 
Another essential term or definition for further consideration in this paper is the concept of "ownership". Aristotle believed that it is the direct extension of natural rights, and despite Christian theories, which seem to depreciate ownership (we all know Matthew 19:16-30 and the example of the camel and eye of the needle) people tended to secure ownership as much as they could over the centuries. By ownership rights I mean the very basic rights to use property in the way preferred by the owner (within legal boundaries, of course), freedom of derive benefits form the property and finally the ability of transferring the ownership to other people or institutions.

Over the centuries, the ownership right was one of the pillars of economic development of Europe and the USA. One of the basis of classic economy was the assumption of an entrepreneur maximizing his own goals that would contribute to the whole economy (Smith 1954).

At the beginning of the $20^{\text {th }}$ century it was still very common to see ownership and management in one hand. To complete our considerations, we need to mention examples when management functions were separated from formal ownership already in medieval cities and universities, but it became a dominating trend in the first half of the last century.

The rapid technological development and the even faster growth of corporations has brought several challenges for the split of management and ownership functions, already named at that time the steward theory, agency theory, and finally, corporate governance theory.

\section{Purpose and objectives of governance}

Before we start reviewing corporate governance theories developed so far, we need to define two terms already mentioned in the Introduction. These two terms are direction and control.

The first term can be understood in our context as an internal need to provide definition of roles and responsibilities of the board of directors and top management, define policies and programs and the response scheme through relevant mechanisms of internal control. The second term, control, should be understood as the determinants of external regulators and government, which include the framework for operations brought by legislation and formalized communication rules embedded, for example, in stock exchange regulations (Larcker, Tayan 2016).

The objectives of governance are different and depend on the group of stakeholders which is concerned (Grabowska, Otola 2015; Skowron-Grabowska, Tozser 2016).

The objectives of the board of directors are defined around understanding of the widely understood company activity and the way the company should act to sustain listing on stock exchange. Advice and guidance issued by the board of directors are the form of realization of the objectives defined in such a way (Larcker, Tayan 2016). Broad understanding of the objectives includes also actions which attract investment. 
Shareholders require safe environment to invest and a clear and transparent way to assess global opportunities. Transparency should also prove accountability and responsibility as the key factors determining the investment environment.

\section{Scope and underlying principles}

So far the scope of governance was defined in relation to direction and control, clearly defined in the sections above. Direction as explained above is based on the internal perspective and includes the definition of corporate structures and roles, procedures and rules of internal control, creating general corporate environment and culture of professionalism and ethics, and finally monitoring and adapting all the above elements in order to meet objectives.

The scope of control includes all forms of legislation related to corporate activity. We can name here, of course, corporate law but also health and safety, labor law, and quite a few aspects of environmental regulations.

The basic principles are often overlooked when describing the activities of the board of directors as obvious. Indeed, they should be obvious but to have a complete view, they are listed below (LSBF 2018):

Fairness - a sense of equilibrium or even-handedness when dealing with others. It is particularly true in stakeholder relations. What is described as being fair is intangible, however it relates close to a societal recognition of what are the expected norms of behavior and a sense of fairness between differing groups such as the fairness of directors pay in relation to the pay received by employees.

Openness/Transparency - a sense of lifting the veil from operations, of creating openness in company operations. Transparency can relate to informing about the financial position and identifying investment or corporate risk. Transparency is supported through disclosure of decision rationale and the use of meetings with shareholders on regular basis (OECD 2004).

Innovation - the ability to introduce changes into an organization or with regard to its business positioning. Innovation is the watch word for organizational success in a fluid, dynamic business environment and, as a principle of governance, commands the board of directors to take actions in the area of measured changes in product and market activities.

Skepticism - can be viewed as a counter balance to innovative drive on the board of directors. A degree of cynicism or reluctance to accept a given idea or belief is necessary until such a belief has been established through reasoned and objective argument. The sense of balance between innovation and skepticism has implications for the board's personality and skills base (LSBF 2018).

Independence - the ability to be unbiased from personal or other influence outside of that prescribed through one's formal role in the organization. Independence is an issue for both directors and their auditors (Larcker, Tayan 2016). Independence requires real detachment and is connected to the need for clarity in terms of what an individual's role should be.

Probity/Honesty - abiding by the legal standards valid in society. There is also more general sense of being an honest player or an individual presents high ethics. 
We may say that honesty has a tangible interpretation relating to adhering to the legal regulations whereas a sense of probity is a sense of fair dealing or honesty in a no so precisely and literally defined societal sense.

Responsibility - it relates to the need to accept liability for one's actions. The willingness and readiness not to hide behind blame placed on others but rather to face ones' own role in the actions of the corporation. A meaning of responsibility could be viewed in a smaller scope with regard to shareholders needs but should be considered in a wider sense of responsibility to country or society as a whole.

Accountability - concerns the development of responsibility. At this point the sense of accepting liability for our actions is extended to include the need to demonstrate this in taking responsibility by communicating actions taken or decisions reached to the interested bodies. Accountability is often seen within the accounts provided to the market or in the wider nature of disclosure. Directors often also account by the Annual General Meeting or even being represented at a parliamentary.

Integrity - a building's integrity relates to its strength or solidity. In case of corporate relation perfect definition was given by one of my lectures in EY Academy - as the ability to do the right things when nobody is watching. An individual can demonstrate integrity through operating by a high moral code of ethics. This integrity must be combined with the influences of self-interest or the pressure placed upon an person by others to act in a way that would result in the integrity of the director.

Judgement - it relates to the ability to weigh issues, to have balance and to not be swayed by emotive issues. Judgement is maintained through information or a formal process of consideration (LSBF 2018). Demonstrating good judgement could be through scrutiny of the performance of the corporation although in an ethical sense good judgement needs consideration of fairness and integrity rather than simply inspecting the results (Oplustil 2010).

Reputation - reputation is an effect of proving adequate adherence to the other underlying principles. Reputation may be observed from individual, entire board or corporate perspective of. If reputation of the individual is questioned their position on the board becomes insecure. If the company's reputation is under question mark this can have a long term damaging effect on results.

\section{Scope of governance (as it is)}

It is not easy to present general scope of governance as it differs from country to country, slightly differently defined by corporate tradition and legislation but I will try to pint out institutions and routines which are the most commonly met.

Board of directors were mentioned quite extensively already - so just few words about precise role in the scope. An effective board of directors should (LSBF 2018; OECD 2004):

- Lead company strategy prudently with effective internal controls and risk management, to maximize sustainable long term success of company. 
- Set the company's values. This includes setting a responsible tone from the top which accepts the fundamental principles of governance, especially a sense of obligation and accountability with regard to stakeholder relationships.

- Should meet regularly, with a formal agenda.

- Should disclose details its membership (including Chairman, CEO, Senior Independent Director, Committee members) and prove transparency in the Annual Report.

- Should ensure Chairman and Non-Executive Directors (NEDs) meet in absence of the Executives, to assess their performance.

- Should ensure NEDs assembly without Chairman annually, to think through the performance of the Chairman.

- Chairman and Chief Executive Officer

- They should not be the same person.

- The Chairman leads the board, and sets the agenda for board meetings, ensuring there is enough time for important matters and all directors contribute.

- The Chairman is the key contact for shareholders.

- The CEO runs the company (Jeżak 2010).

- Board composition

- No one person, or group of individuals, should be capable to dominate the board.

- Should be an correct size, and right balance of skills and experience. This contains diversity, including by gender.

- Appointments to the board

- Have objective merit-based criteria for selection of new board members.

- Oversee induction and training for all directors (likely to be organized by the Chairman, assisted by the Company Secretary).

- Annual performance review

- The Board, its committees, and individual directors should have performance evaluated at least once per year.

- Re-election of board members

- At 1st AGM after nomination to board, and at least every 3 years afterwards, by shareholders (note, for FTSE 350 companies, all directors are up for re-election every year).

- If not annual re-election for all directors, practical to "retire by rotation" and avoid potentially losing all the board at once.

- Remuneration of directors (Oplustil 2010)

- A significant percentage should be performance-related.

- Should include industry pay levels.

- Sufficuent to attract, retain and motivate.

- Notice periods no should not be longer than 1 year.

- Internal control

- The Board should ensure a sound system of Controls.

- An annual review of effectiveness of controls is required and should be reported in the Annual Report. 
- There should be an Audit Committee of at least 3 Independent NEDs (Non-Executive Directors) (Jeżak 2010).

- The main role of the Audit Committee is liaison with the internal and external auditors on all matters.

- Relations with shareholders

- There should be regular dialogue with shareholders.

- The Chairman is to ensure shareholder views are communicated to the Board.

- Communicate with investors and encourage debate through AGM.

\section{Challenges of governance in digital world}

Intangible companies. First venture of converting global is potential to exist of companies which can be built as an alternative around concept and generated instead of conventional version with fixed assets, buildings, places of work, belongings and production facilities.

Example of an organization developing a great deal quicker than concept of governance is Uber.

Uber technology was established in 2009 by Travis Kalanick, Garrett Camp, and Ryan Graves. Kalanick became a serial entrepreneur with a computer science experience, having established businesses previous to Uber, the latter of which he offered to Akamai in 2007 for \$ 15 million. In 2009, Kalanick and Camp conceived of the concept of a mobile app that might be used to reserve rides from non-public drivers on demand after the two experienced trouble catching cab rides in San Francisco. Graves became in short introduced on as CEO earlier than Kalanick took over (Larcker, Tayan 2017).

From the start, Kalanick launched into an competitive campaign to dominate the ride-sharing business, increasing first throughout the U.S. after which across the world. with the aid of 2014 - less than 4 years after launching its app - Uber became operating in greater than 250 towns in 53 international locations. "It's likely the fastest international expansion that I've ever seen from a venture-backed company", located an early investors (Rusli, MacMillan 2014). Revenue, which become a hundred twenty five million in 2013, rose to $\$ 6.5$ billion 3 years later. The words of an early worker, Kalanick's become recognized "increase above all else". This attitude stored inside the corporation's 14 cultural values, which advocated behaviors inclusive of "usually be hustling", "make magic", and "toe-stepping".

Further records of Uber indicates us how incomplete corporate Governance equipment we've got in hands of stakeholders. Speedy boom and competitive police embedded in the those boom is a center value of the corporation. This single declaration undermines all listing of conventional values relating to idea of stability and harmonic coexistence of stake holders.

Significance of reputation as fundament of organization isn't anything new, however within the scenario of a approach described as above it have to have priority remedy as organization through definition understanding its enterprise version negatively affects public relation problems. 


\section{Digitalization effect in board rooms}

Organizations also are exposed the robbery of proprietary technology or methods of manufacturing. In 2016, US steel become attacked by means of hackers allegedly connected to the Chinese authorities who stole techniques for generating light-weight metal. That same year, Monsanto observed that an worker had been cooperating with a overseas authorities to thieve information on the company's advanced seed technology. The worker loaded "noticeably state-of-the-art and unauthorized software program" on his pc that allowed a foreign government to screen his activity remotely and transmit proprietary records.

Greater mundane however probably extra beneficial cybercrimes contain the robbery of corporate information shared among organizations and their advisors. As an instance, in 2016, distinguished law firms Cravath Swaine and Weil Gotshal had been amongst several of advisory firms hacked by using cybercriminals who stole nonpublic data on corporate customers, which could probably be used for insider buying and selling. In addition, the servers of accounting company Deloitte had been hacked and documents for a small variety of clients had been accessed. In 2017, the Securities and exchange commission found out that Edgar, the database that stores the corporate filings of all publicly traded organizations indexed in the U.S., had been accessed, even though the agency did not disclosed what records become stolen.

Eventually, organizations and their delivery chains were compromised by way of ransomware assaults wherein cybercriminals disrupt computing structures or call for payment underneath threat of disrupting systems. Important assaults passed off in 2017. The primary concerned a ransomware software known as Wanna Cry which infected computer systems using Microsoft Windows operating system. (Vigliarolo 2017) the program mechanically encrypted laptop information and demanded charge in Bitcoin for its release. Over two hundred computer systems in one hundred fifty international locations were affected. FedEx and Nissan mentioned being materially impacted (CNBC 2017). A second malware assault in July 2017 took down the computing systems of main multinational businesses consisting of Merck, Mondelez, and Maersk - and disrupted enterprise operations over a couple of days. Maersk declared that significant pc outages prevented the corporation's transport subsidiary from reserving new shipments and imparting charges at selected terminals (Kostov, Paris 2017). Mondelez anticipated that the attack reduced $2 \mathrm{~d}$-quarter sales increase by three percent points.

Regardless of the sample of escalation introduced above, consistent with Stanford researchers only $30 \%$ of all board meeting even touches trouble of cyber-protection. Individuals of boards are not usually prepared to take into account and counter act to modern threat linked with cybercrimes. 


\section{Conclusions}

Conclusion of the paper is constant need of adjustments in Corporate Governance rules principles and institutions. Examples brought above proved that we cannot rely on current approach to governance as such approach faced with challenges of digital era is going to fail. In both principle based approach and also regulated approach it is necessary to introduce working frameworks which are ready to accommodate situation from highly digitalized world.

\section{Literature}

1. Adams N. (1999), Próby reformowania brytyjskiego systemu nadzoru właścicielskiego, [in:] Rudolf S.(red.), Nadzór wtaścicielski w spótkach prawa handlowego, Wydawnictwo

Naukowe PWN, Warszawa.

2. Bensinger G. (2017), Uber CEO Takes a Break as Scandals Roil Firm, "TheWall Street Journal", June 14.

3. Brzozowska A., Pawełoszek I., Turek T. (red.) (2016), Wiedza i technologie informacyjne w zarzadzaniu procesami biznesowymi, Wydawnictwo Wydziału Zarządzania Politechniki Częstochowskiej, Częstochowa.

4. Cadbury Committee (1992), Report of the Committee on the Financial Aspects of Corporate Governance, Gee, London.

5. CNBC (2017), Unprecedented' Cyberattack Hits 200,000 in at Least 150 Countries, and the Threat is Escalating, CNBC (May 14, 2017).

6. Grabowska M. (2015), Implementacja zasad ładu korporacyjnego a konkurencyjność spółek, [in:] Jerzemowska M., Stańczak-Strumiłło K. (red.), Wspótczesne problemy nadzoru korporacyjnego, Wydawnictwo Uniwersytetu Gdańskiego, Gdańsk, p. 53-70.

7. Grabowska M. (2016), Sytuacyjne konteksty ładu korporacyjnego, Wydawnictwo Wydziału Zarządzania Politechniki Częstochowskiej, Częstochowa.

8. Grabowska M., Otola I. (2015), Corporate Governance in Turbulent Times, [in:] The Possible Positive Aspects of Economic Crises. 2015 Global Business Conference (GBC), Sibenik, Croatia, Innovation Institute, Zagreb, p. 69-79.

9. Guillen M.F. (2000), Corporate Governance and Globalisation: Is There Convergence Across Countries?, The Wharton School and Department of Sociology, University of Pennsylvania.

10. Isaac M. (2017a), Uber Tallies the Costs of Its Leader's Drive to Win at Any Price, "The New York Times", April 24.

11. Isaac M. (2017b), Uber Uses Tech to Deceive Authorities Worldwide, "The New York Times", March 4.

12. Jeżak J. (2010), Ład korporacyjny. Doświadczenia światowe oraz kierunki rozwoju, C.H. Beck, Warszawa.

13. Kostov N., Paris C. (2017), Cyberattack's Fallout Fuels Scramble, "The Wall Street Journal", June 29.

14. Larcker D., Reiss P., Tayan B. (2016), Critical Update Needed-Cybersecurity Expertise in the Boardroom, Stanford Closer Look Series, Corporate Governance Research Initiative, November.

15. Larcker D., Tayan B. (2011), Corporate Governance Matters: A Closer Look at Organizational Choices and Their Consequences, FT Press.

16. Larcker D., Tayan B. (2017), Governance Gone Wild: Epic Misbehavior at Uber Technologies, Stanford Closer Look Series, Corporate Governance Research Initiative, December. 
17. LSBF (2018), ACCA Pl Study Manual 2017/18, London School of Business and Finance, Interactive Worldwide, London.

18. Menn J., Somerville H. (2017), Uber Fires 20 Employees after Harassment Probe, "Reuters News", June 6, https://www.reuters.com/article/us-uber-sexual-harassment/uber-fires-20employees-after-harassment-probe-idUSKBN18X2GZ (accessed: 21.08.2017).

19. Mohamed A., Ratnatunga J. (2008), Do Accounting and Finance Tools Serve Governance?, CARF F-Series CARF-F-127, Center for Advanced Research in Finance, Faculty of Economics, The University of Tokyo.

20. Morgan S. (2016), Why J.P. Morgan Chase \& Co. Is Spending a Half Billion Dollars on Cybersecurity, "The New York Times", January 30.

21. Newcomer E. (2017), In Video, Uber CEO Argues with Driver Over FallingFares, Bloomberg, https://www.bloomberg.com/news/articles/2017-02-28/in-video-uber-ceo-argueswith-driver-over-falling-fares (accessed: 17.06.2017).

22. OECD (2004), OECD Principles of Corporate Governance, Organisation for Economic Co-Operation and Development, Paris, http://www.oecd.org/corporate/ca/corporategoverna nceprinciples/ 1557724.pdf (accessed: 02.10.2017).

23. Oplustil K. (2010), Instrumenty nadzoru korporacyjnego (corporate governance) $w$ spótce akcyjnej, C.H. Beck, Warszawa.

24. Ponemon Institute (2016), 2016 Cost of Data Breach Study: Global Analysis, Ponemon Institute, Michigan.

25. Rusli E.M., MacMillan D. (2014), Uber Fetches $\$ 18.2$ Billion Valuation - Car Service App Worth More Than Hertz, "The Wall Street Journal”, June 7.

26. Skowron-Grabowska B., Tozser J. (2016), The Problems of Corporate Social Responsibility. The Issues of the Economic Theory and Practice, [in:] Brzozowska A., Pawełoszek I., Turek T. (red.), Wiedza i technologie informacyjne $w$ zarzadzaniu procesami biznesowymi, Wydawnictwo Wydziału Zarządzania Politechniki Częstochowskiej, Częstochowa, p. 181-190.

27. Smith A. (1954), Badania nad naturą i przyczynami bogactwa narodów, t. 1, PWN, Warszawa.

28. Staff R. (2017), Uber Used Secret Tool to Evade Authorities, "Reuters News", March 4, https://www.reuters.com/article/us-uber-greyball-idUSKBN16A2IL?feedType=RSS\& feedName=newsOne (accessed: 20.08.2017).

29. Uber CEO Says He Must 'Grow Up' After Argument with Driver, "Reuters News", March 1.

30. Vigliarolo B. (2017), 10 Major Organizations Affected by the Wanna Cry Ransomware Attack, TechRepublic, https://www.techrepublic.com/pictures/gallery-10-major-organizations -affected-by-the-wannacry-ransomware-attack/ (accessed: 20.06.017).

\section{ŁAD KORPORACYJNY W EPOCE CYFROWEJ - PODSTAWY TEORETYCZNE}

Streszczenie: Ciągle rosnąca szybkość postępu technicznego wraz z towarzyszącymi zmianami w modelu zachowań społecznych człowieka zmieniają bardzo prędko obraz przedsiębiorstw. Ład korporacyjny wymaga również szybkich adaptacji, aby nadążyć za tymi zmianami. Ale czy to w ogóle możliwe? Czy można tak zdefiniować filary stabilności i przejrzystości, by jednocześnie umożliwiały dynamiczne dostosowania? Kilka przykładów praktycznych z zakresu problemów ładu korporacyjnego ilustruje, jakie pytania powstają i jakie problemy rodzą się przy próbie rozszerzenia zakresu tradycyjnego rozumienia tematu poprzez wyzwania dnia jutrzejszego, które nadeszły dzisiaj.

Słowa kluczowe: teoria agencyjna, Big Data, ład korporacyjny, cyfryzacja, służebność 